\title{
PERANAN PEREMPUAN DI LUAR RUMAH TANGGA DALAM PERSPEKTIF HISTORIS
}

Oleh

Dina Dwikurniarini ${ }^{1}$

\begin{abstract}
Abstrak
Ajaran yang selama ini dikenalkan pada kita adalah bahwa perempuan diciptakan dari tulang rusuk pria. Anggapan tersebut telah menempatkan perempuan sebagai subordinasi pria. Bahkan kebudayaan kita juga mengajarkan perempuan sebagai mahkluk nomor dua. Oleh karena kedudukannya tersebut maka dalam seluruh aspek kehidupan perempuan tidak mempunyai peranan penting. Fungsi reproduksinya menjadikan perempuan tidak punya banyak waktu untuk berperanan dalam sektor publik, karena kewajibannya mengasuh anak. Mengurus rumah tangga adalah kewajibannya yang utama. Meskipun peran itu sangat penting tetapi dalam anggapan budaya tetap menempatkannya sebagai peran sekunder, karena mencari nafkah dilakukan suami adalah penting untuk meneruskan hidup.

Melekatnya stigma sebagai “konco wingking” terus membayanginya. Betulkah sejak dahulu perempuan tidak mempunyai peran dalam rumah tangga terutama dalam sektor ekonomi? Tulisan singkat ini akan melihatnya dari aspek historis keberadaan perempuan di luar rumah tangganya. Pembahasan menekankan pada keterlibatan perempuan dalam perkembangan ekonomi masa kolonial.
\end{abstract}

Kata Kunci: Konco wingking, nomor dua, perempuan, pria, dan sector publik.

\section{A. Pendahuluan}

John Naisbith dan Patriacia Aburdens dalam bukunya Megatrend 2000, meramalkan bahwa abad ke 21 adalah abadnya perempuan. Abad 21 baru berjalan 6 tahun tetapi tanda-tanda itu belum begitu banyak membahas perempuan sekalipun dalam bidang politik, ekonomi, sosial budaya tetap sama seperti masa-masa sebelumnya. Dalam perekonomian di Indonesia terdapat kenaikan angkatan kerja wanita dari 22.216.000 tahun 2001 menjadi 22.669 .000 (2002) tetapi menjadi 22.174.000 (2002) dan 20.727.000 $(2003)^{2}$. Sedangkan penduduk perempuan yang bekerja di tahun 2000 di Jawa tercatat

\footnotetext{
${ }^{1}$ Adalah pengajar di Prodi Ilmu Sejarah dan di Unit Mata Kuliah Umum

${ }^{2}$ http:/www. Nakertrans. Go.id/ pusdatinnaker/BPS/AK/AK\% 20 pulau jekel \% 20203 htm. $1 / 25 / 2005$.
} 
20.717.000 dan seluruh Indonesia 34.399.000. Pekerjaan utama disektor pertanian 14,994, Tata Usaha pertanian 14,974, perdagangan 8, 478, sebagai buruh atau karyawan 10.250. Angka-angka tersebut dapat menepis anggapan selama ini bahwa perempuan tidak mempunyai peran dalam ekonomi keluarga.

Keterlibatan perempuan dalam ekomi dapat dijelaskan dari berbagai contoh studi sejarah. Sejak dibukanya industri perkebunan di Jawa tahun 1870 menunjukkan adanya perempuan yang terlibat dalam sektor produksi tersebut. Jauh sebelumnya perempuan telah terlibat dalam sektor agraris. Meskipun keberadaannya tidak mudah karena adanya persaingan dengan pria maupun sesama perempuan, tetapi mereka tetap dibutuhkan.

Di dalam masyarakat agraris pekerjaan merupakan pekerjaan keluarga ${ }^{3}$. Seluruh organisasi petani ditentukan oleh ukuran dan komposisi keluarga petani dan tuntutantuntutan konsumsinya dengan jumlah tangan yang bekerja. Ini berarti seluruh keluarga terlibat didalamnya, misalnya ibu merawat anak yang masih kecil, menyediakan makan, suami melakukan pekerjaan kecil dirumahnya, anak laki-laki yang agak besar mencari rumput. Pekerjaan-pekerjaan tersebut dilakukan dengan senang hati dan tidak memperhitungkan untung ruginya dan pekerjaan itu juga tidak memerlukan biaya ${ }^{4}$. Perempuan dalam masyarakat agraris tentu punya peran besar dirumahnya, karena kalau perannya digantikan pembantu maka suami harus menyediakan biaya tambahan. Disamping perempuan mengerjakan pekerjaan dirumahnya, mereka juga masih membantu suami di sawah.

Data BPS di atas meski menunjukkan ada peningkatan jumlah perempuan bekerja secara kuantitatif saja belum kualitatif, karena jenis pekerjaan mereka masih dinilai

\footnotetext{
${ }^{3}$ Eric R Wolf. Petani Suatu Tinjaun Antropologi. Jakarta: CV Rajawali, 1985, hlm. 21.

${ }^{4}$ Ibid.
} 
pekerjaan kasar ${ }^{5}$. Semakin meningkatnya perempuan dalam kegiatan ekonomi ditandai dua proses yaitu pertama, peningkatan jumlah wanita yang terlibat dalam pekerjaan diluar rumah tangga (oud door activities) dari 32,43\% tahun 1980 menjadi 38, 79\% tahun 1990. Kedua, peningkatan dalam “jumlah bidang pekerjaan” yang dapat dimasuki oleh perempuan ${ }^{6}$ bahkan tidak jarang menggeser pria pada berbagai sektor.

Perkembangan tersebut menandakan perkembangan kuantitatif penting dalam kehidupan perempuan karena adanya kesempatan-kesempatan yang semakin terbuka seperti pendidikan, sosial budaya dan ekonomi. Keadaan tersebut karena dipengaruhi faktor-faktor yang saling terkait baik pada perempuan sendiri maupun norma-norma yang telah berubah. Sebagai contoh melalui proses urbanisasi sejak tahun 1970an banyak perempuan mencari kerja ke kota dengan menetap atau hanya tinggal sementara ${ }^{7}$. Menurut Kartini Syahrir perempuan berurbanisasi paling tidak dipengaruhi 5 hal yaitu 1) Perempuan bermigrasi dari desa ke kota akan mempengaruhi perubahan desa karena perempuan punya peran ekonomi tersendiri dalam kehidupan ekonomi desa; 2) Motif berbeda tergantung status perkawinan, hambatan agama dan kultural serta tingkat upah; 3) adanya konsekuensi sosial dari migrasi bagi perempuan dalam kaitan dengan nilainilai moral gaya hidup moderen di perkotaan. Konsekuensi akan berbeda antara perempuan yang menikah dan lajang; 4) migrasi perempuan berpengaruh pada keluarga sebagai lembaga. Terputusnya hubungan dengan keluarga di desa sedikitnya mempengaruhi sikap migran perempuan, yang sudah menikah menentukan kedudukannya dalam keluarga; 5) perhatian terhadap masalah migran perempuan

\footnotetext{
${ }^{5}$ Irwan Abdullah. "Reproduksi Ketimpangan Gender Partisipasi Wanita Dalam Kegiatan Ekonomi” Prisma Majalah Kajian Ekonomi dan sosial No. 6 Tahun 1995. LP3ES. hlm. 3.

${ }^{6}$ Ibid.
} 
seringkali tidak dihitung dalam proses migrasi karena anggapan yang salah bahwa mahkluk pasip ${ }^{8}$.

Kesempatan perempuan untuk keluar ruang domestiknya dan bekerja diluar rumah atau melakukan kegiatan lain (wanita migran) dipengaruhi oleh kesadaran baru atau karena pergeseran sistem nilai sehingga memungkinkan mereka meninggalkan rumah. Pergeseran tersebut juga sebagai tanda adanya permintaan pasar akan tenaga perempuan atau lembaga yang memberi jaminan dan membina peluang untuk itu. Peningkatan itupun hanya untuk tenaga kasar dari 9,12\% tahun 1971 menjadi 15,07\% tahun 1980 dan 16,26\% tahun $1990^{9}$. Keadaan itu menunjukkan pada ketimpangan gender yang dapat dilihat: 1) melihat akar sosial budaya dimana ketimpangan gender itu tersusun menjadi suatu realitas objektif; 2) melihat proses pemberian makna dan pemeliharaan ketimpangan itu secara terus menerus; 3) melihat pada integrasi pasar yang memiliki peran penting dalam proses segmentasi yang kemudian menempatkan perempuan pada segmen tertentu dan pria pada segmen yang lain ${ }^{10}$.

Pada dasarnya pria berada dibidang publik dan perempuan bidang domestik. Laki-laki pada produktif dan perempuan pada konsumtif. Perbedaan itu menunjukkan adanya negosiasi kekuasaan antara laki-laki dan perempuan. Konsumsi terlihat pada produksi, karena produksi diurus laki-laki maka perempuan akhirnya juga di bawah kontrol laki-laki ${ }^{11}$. Perempuan yang berada pada sektor domestik dianggap tidak penting apalagi dalam masyarakat moderen yang menekankan pada produksi dan birokrasi. Oleh karena itu perempuan perannya ditentukan oleh laki-laki. Mitos-mitos selama ini

\footnotetext{
${ }^{7}$ Kartini Syahrir. “Wanita: Beberapa Catatan Antropologi” Prisma majalah Ekonomi Sosial No. 10 1985 Th. XIV LP3ES, hlm. 10.

${ }^{8}$ Ibid.

${ }^{9}$ Irwan Abdullah, op. cit. hlm.5.
} 
menyatakan bahwa laki-laki adalah di dunia kerja, sementara perempuan ditempatnya di rumah. Realitas tersebut merupakan suatu ideologi yang sudah dipercaya berabad-abad lamanya. Peran domestik menyebabkan perempuan tidak punya kesempatan ke luar rumah dan bertemu orang atau hal-hal baru. Perannya itu tidak dihargai dalam budaya.

\section{B. Perempuan Sebagai Mahkluk Sekunder}

Secara biologis manusia perempuan dan laki-laki memang tidak sama, tetapi sebagai mahkluk jasmani dan rohani mereka dilengkapi akal budi dan kehendak bebas yang menyebabkan mereka secara hakiki ada kesamaan. Perempuan dan laki-laki punya hak yang sama untuk berkembang, meskipun dalam kenyataan di negara maju maupun di negara berkembang perempuan dianggap “warga negara kelas dua” yang selalu kesulitan untuk menikmati haknya sebagai manusia bebas.

Sejak kapan perempuan menjadi “kelamin kedua” di bawah subordinasi pria dapat dijelaskan dalam ata arkeologis mengenai kehidupan dan kebudayaan penduduk zaman pra sejarah. Pada periode palelitikum yang berakhir tahun 12.000 SM, penduduk mengumpulkan pangan dengan berburu dan mencari ikan. Mengingat berburu (hunter) menunjukkan bahwa hanya prialah yang mampu melakukannya ${ }^{12}$.

Berburu bukan hanya aktivitas ekonomi melainkan seluruh aktivitas kehidupan pria. Zaman moderen pun pria juga menyukai berburu meskipun tidak ada nilai ekonomisnya. Berburu menjadi kegiatan laki-laki yang membedakannya dengan perempuan. Man the Hunter digambarkan dengan fisik kuat, kekar dan rasional sehingga

\footnotetext{
${ }^{10}$ Ibid. hlm. 6.

${ }^{11}$ Ibid.

${ }^{12}$ Darsiti Soeratman. "Wanita Indonesia: Lampau, Kini dan Mendatang”. Pidato Ilmiah Dalam Rangka Acara Pembukaan Kuliah Prigram Pasca Sarjana Semester I di UGM, 2 September 1991. hlm. 2
} 
mampu menangkap hewan buas dengan kasar dan membunuhnya. Man = manusia yang sinonimnya male = laki-laki, sehingga berburu tidak hanya merupakan aktivitas ekonomi melainkan sebagai seluruh pola aktivitas kehidupan kaum pria ${ }^{13}$. Oleh karena itu Domination Rape merupakan kejahatan perkosaan laki-laki terhadap perempuan karena ingin menunjukkan superriorotasnya sebagai laki-laki dan tujuan akhirnya adalah menaklukakan perempuan secara sexual. Sebaliknya perempua dianggap sebagai kaum lemah, emosional, memerlukan perlindungan, kurang inisiatif, pasif, kurang dinamis dan lebih submisif dari pria ${ }^{14}$.

Kaum laki-laki sebagai pemburu secara kultural dapat membawanya pada kemajuan lebih cepat dari perempuan karena dengan pergi berburu sendiri ataupun berkelompok, mereka akan saling bekerjasama maupun belajar, seperti tekhik berburu, menciptakan alat-alat berburu dan berkomunikasi. Dalam berburu mereka tidak mengajak istri atau anak-anak mereka. Oleh karena itu istri pemburu tidak bertugas menjaga anak dan rumah tetapi juga harus mencari makan disekitar rumahnya.

Struktur yang timpang tersebut telah menempatkan perempuan pada sisi lain dan laki-laki pada sisi yang lain juga dalam satu garis vertikal. Kedudukan mereka dibedakan pada wilayah ekspresi yang memberi kekuasaan pada laki-laki dalam berbagai kegiatan ekonomi ${ }^{15}$.Akan tetapi kemajuan dalam berbagai bidang memantapkan pembagian kerja berdasar sexual yang akarnya telah tumbuh sejak zaman palaelitikum.

Laki-laki leluasa melakukan aktivitas publik sehingga memungkinkannya berkembang dan maju, sementara perempuan disibukkan dengan pekerjaan rumah

\footnotetext{
${ }^{13}$ Ibid.

${ }^{14}$ Ibid

${ }^{15}$ Irwan Abdullah, op. cit. hlm. 8.
} 
tangga. Keunggulan pria membuat perempuan mulai dihinggapi perasaan inferior hingga sekarang.

\section{Perempuan Sebagai Second Labour dalam Produksi}

Ideologi yang menekankan bahwa peran perempuan yang utama adalah disekitar rumah tangga sebagai ibu dan istri telah berabad-abad disosialisasikan dan diinternalisasikan dalam masyarakat Jawa $^{16}$. Ideologi tersebut dalam masyarakat Jawa telah diredefinisikan melalui hukum-hukum adat, kepercayaan-kepercayaan, negara dan pemerintah yang pernah ada dalam sejarah. Di zaman kerajaan, perempuan kelas atas digambarkan sebagai mahkluk anggun, halus, rapi, tetapi tidak punya pikir tinggi dan tidak memiliki kemampuan serta tidak spiritual sehingga dianggap tidak mampu menduduki jabatan-jabatan strategis dalam pemerintahan dan masyarakat ${ }^{17}$. Pandangan tersebut berbeda pada masyarakat umum atau miskin yang justru mempunyai peran ganda sebagai ibu rumah tangga (housewifization) dan mencari nafkah. Meskipun demikian pekerjaan perempuan dikatakan "bukan produktif”18.

Disejumlah masyarakat petani pembagian kerja berdasarkan gender merupakan cara efisien untuk menjamin kelangsungan hidup dan beradaptasi dengan lingkungan tertentu $^{19}$. Pemerintah kolonial mengambil peran perempuan dalam masyarakat Hindia Belanda sebagai model dan beranggapan bahwa perempuan tidak bisa dan seharusnya tidak bisa atau tidak bekerja untuk mendapat $u^{20}{ }^{20}$. Masa liberalisasi di Hindia Belanda

\footnotetext{
${ }^{16}$ Irwan Abdullah, ed. Sangkan Paran Gender. Yogyakarta: Pustaka Pelajar, 1997. hlm. 90.

${ }^{17}$ Ibid.

${ }^{18}$ Mansoer Fakih. Analisis Gender dan Transformasi Sosial. Yogyakarta: Pustaka Pelajar, 2001.

${ }^{19}$ Julia Cleves Mosse. Gender Pembangunan. Yogyakarta: Pustaka Pelajar, 1996. hlm. 28.

${ }^{20}$ Ibid.
} hlm. 21. 
jumlah tenaga perempuan sedikit atau $10: 1$, sepulih tenaga pria 1 tenaga wanita ${ }^{21}$. Lebih banyak kuli laki-laki di perkebunan berlaku untuk semuanya baik orang Eropa, Jawa, maupun Cina. Pada akhir abad ke 19 buruh perempuan hanya sekitar 10\% hingga 12\% dari jumlah keseluruhan buruh Asia yang berjumlah 55.000 orang lebih dan pada 1912 terdapat sekitar 100.000 di perkebunan di Deli ${ }^{22}$. Kebutuhan akan tenaga laki-laki di perkebuan Deli tidak sama dengan di perkebunan the Malabar yang justru lebih banyak buruh perempuannya.

Sejalah dengan kebijaksanaan ekonomi kolonial adalah pengerahan tenaga kerja khususnya di Priangan, maka penyediaannya bertumpu pada kerangka rumah tangga. Dalam hal ini perempuan punya andil besar ketika sektor agraris tidak lagi mampu menampung mereka. Mengalirnya tenaga kerja perempuan di perkebunan teh merupakan fenomena yang menarik setelah terbukanya wilayah Priangan. Pengerahan tenaga kerja uuntuk perkebunan the dibedakan dua. Pertama, pengerahan tenaga dalam rangka kerja wajib penduduk desa. Kedua, pengerahan tenaga melalui perantara yang biasanya dikuasai oleh orang-orang $\mathrm{Cina}^{23}$.Mereka yang tergolong kerja wajib mempunyai tanggung jawab ganda yaitu sebagai tenaga kerja diperkebunan dan digaji, tetapi mereka masih punya tanggung jawab terhadap desa yaitu pada penguasa desa terutama ketika penguasa memerlukan untuk panen. Pengerahan tenaga kerja pwewmpuan melalui agen perantara Cina biasanya dengan pemberian uang muka pada perempuan-perempuan desa sebagai ikatan kerja ${ }^{24}$. Sasaran mereka adalah dari kelompok petani. Selama dalam kerja

\footnotetext{
${ }^{21}$ Sartono Kartodirdjo dan Djoko Suryo. Sejarah Perkebunan di Indonesia Kajian Sosial Ekonomi. Yogyakarta: Aditya Media, 1991, hlm. 152. .

${ }^{22}$ RP Suyono. Seks dan Kekerasan Pada Zaman Kolonial. Penelusuran Kepustakaan Sejarah. Jakarta: PT Gramedia Widia Sarana Indonesia, 2005, hlm. 115-116

${ }^{23}$ Fatia Nadia. "Tenaga kerja Wanita di perkebunan Teh Malabar Afdelingen Cianjur Regenschapen Priangan Tahun 1880-1900”. Skripsi Sarjana Fakultas Sastra UGM tahun 1987, hlm. 21.

${ }^{24}$ Ibid. hlm. 22.
} 
wajib desa, pihak perkebunan juga tidak membayar upah, sedangkan tenaga kerja perempuan yang jadi sasaran adalah mereka yang ditinggal suami dalam rangka mencari kerja di luar desanya.

Perlakuan gender dalam perkebunan terikat juga dengan sistem upah. Pengupaham per jam untuk buruh laki-laki berkisar antara 3-4 sen, sedangkan untuk buruh perempuan menerima 2-3 sen ${ }^{25}$. Penghasilannya yang rendah tidak mencukupi untuk memenuhi kehidupan keluarga. Untuk dapat memenuhi kebutuhan sehari-hari perempuan buruh pemetik akan mempekerjakan anak-anaknya. Perbedaan upah antara buruh laki-laki dan buruh perempuan juga terjadi di perkebunan Sumatra Timur yang tidak menunjukkan kenaikan selama kurang lebih 30 tahun, seperti dalam tabel dibawah ini. Permasalahan lain yang dihadapi buruh perempuan adalah produktivitasnya dinilai rendah dibanding buruh laki-laki.

Tabel. Upah Buruh di Perkebunan Sumatra Timur 1913-1940 dan sen per hari ${ }^{26}$

\begin{tabular}{|c|c|c|}
\hline Tahun & Upah Buruh laki-laki & Upah buruh Perempuan \\
\hline 1913 & 43 & 43 \\
1920 & 54 & 42 \\
1925 & 52 & 44 \\
1930 & 58 & 30 \\
1935 & 49 & 29 \\
1940 & 52 & \\
\hline
\end{tabular}

\footnotetext{
${ }^{25}$ Mubyarto, dkk. Tanah dan Tenaga Kerja Perkebunan Kajian Sosial Ekonomi. Yogyakarta: Aditya Media, 1992, hlm. 111.

${ }^{26}$ Ibid. hlm. 120.
} 
Padahal sebenarnya pekerjaan yang memerlukan ketekunan dan ketelitian lebih baik jika dikerjakan perempuan. Di Jawa Timur 3 perusahaan tembakau 78,3 tenaga kerjanya adalah perempuan ${ }^{27}$. Pekerjaan yang lain untuk perempuan adalah sebagai pengurus rumah tangga orang-orang Belanda atau orang-orang kaya pribumi. Pekerjaannya seperti biasa mereka lakukan dirumahnya, tetapi untuk kepentingan majikannya.

\section{Tantangan Perempuan di Luar Rumah}

Dalam masyarakat desa pra kapitalis peran perempuan sangat penting. Lalu lintas yang ada di desa hampir semua ditangani perempuan. Laki-laki sangat kurang tahu urusan-urusan uang dan mudah dibujuk. Jika beras simpanan habis atau menipis, suami yang ditanya akan makan dari mana, akan menjawab "terserah istri saya” ${ }^{28}$. Seorang suami petani hampir sepanjang hari membajak, mencangkul, pengawasi pengairan sawahnya serta memikul beban. Sementara istrinya menuai, menjaga ternak, menyiapkan makan, mengurus pakaian, serta membawa hasil bumi ke pasar desa. Sementara lain perempuan menenun, memintal, membakar tembikar, mengumpulkan hasil hutan serta mengemudikan perekonomian rumah tangga. Rasanya tanpa bantuan perempuan tidak ada seorangpun di desa dapat hidup secara mandiri, karenanya istri dan tanah adalah hakiki bagi manusia laki-laki ${ }^{29}$.

Perempuan di pedesaan dapat dikelompokkan dalam dua peran yaitu peran tradisi dan peran transisi ${ }^{30}$. Peran tradisi atau domestik mencakup peran perempuan istri dan ibu yang mengatur rumah tangga. Sementara peran transisi meliputi pengertian wanita

\footnotetext{
${ }^{27}$ Ibid. hlm. 126.

${ }^{28}$ JH Boeke. Pra Kapitalisme di Asia. Jakarta: Sinar Harapan, 1983. hlm. 28.

${ }^{29}$ Ibid.
} 
sebagai tenaga kerja, anggota masyarakat dan manusia pembangunan. Ketika menjalankan peran tradisi, perempuan mendampingi suami, melayani bahkan mengabdi pada suami, mengatur, menyiapkan dan menyajikan kebutuhan pangan dan gizi seluruh keluarga. Sebagai anggota rumah tangga mendidik anak, mengelola kebersihan dan kenyamanan rumah tinggal mereka. Sementara peran transisi perempuan ikut aktif dalam kegiatan perekonomian sesuai dengan kemampuan, pendidikan dan kesempatan serta tersedianya jenis pekerjaan.

Keberadaan tenaga kerja di masa kolonial diatur dalam Ordonance no. 647 tahun 1925 tentang tenaga kerja anak-anak dan perempuan. Tahun 1969 keluar Gouvernmen Declared Act no. 14 dan Article no. 10 Ac no. 144 tahun 1969 yang mengatur: a. standar keselamatan, b. standar keselamatan kerja dan kesehatan dalam industri, c. standar tenaga kerja dan d. kompensasi kesehatan dan rehabilitasi dalam kecelakaan industri ${ }^{31}$.Kebijakan tersebut seharusnya menjadi jaminan akan keselamatan perempuan diluar rumah tangganya ketika ia tidak mendapatkan perlindungan suaminya. Ada tiga masalah yang dihadapi perempuan bekerja: 1) Indonesia adalah negara yang pluralistik dalam etnik dan kebudayaan; 2) adanya hal itu tidak mungkin untuk membuat generalisasi bahwa perempuan berkedudukan rendah tanpa mempelajari kedudukan perempuan dalam konteks budaya dari masing-masing suku di Indonesia. Dalam masyarakat Minangkabau mendudukkan perempuan sejajar dengan pria karena perempuan menjaga harta pusaka

\footnotetext{
${ }^{30}$ Handewi P Suliem. "Potensi dan Partisipasi Wanita Dalam kegiatan Ekonomi Pedesaan. Prisma Majalah Kajian Ekonomi dan Sosial No. 6 tahun 1992, LP3ES, hlm. 19.

${ }^{31}$ Ninasapti Triaswati. "Woman and Children Labour Force in the Indonesia". Indonesian Quarterly vol. XXIV No. 1 1996, CSIS. hlm. 19-20.
} 
keluarga; 3) situasi dilematis yang dihadapi perempuan Indonesia merupakan hasil suatu proses interaksi dari berbagai faktor sosial dan politik yang berkembang di Indonesia ${ }^{32}$.

Keberadaan perempuan dalam sektor produksi telah menimbulkan perdebatan antara anggota Volksraad tahun 1925 dan wakil pemilik perkebunan, mengenai apakah perempuan diizinkan bekerja pada malam hari atau tidak ${ }^{33}$. Anggota Volksraad yang semua laki-laki mendukung usul yang melarang perempuan kerja malam hari, mereka beranggapan bahwa pemerintah wajib melindungi perempuan secara fisik dan perempuan juga harus berada ditengah-tengah keluarga. Kalau perempuan diizinkan kerja malam maka akan mengabaikan suami dan anak-anaknya. Keharusan berada di rumah menunjukkan bahwa perempuan adalah mahkluk lemah. Sedangkan izin untuk bekerja adalah konsep Barat yang dipengaruhi oleh agama Kristen, yang mengajarkan perempuan adalah the Weaker Vessel, demi kepentingan perempuan sendiri maka mereka tidak diijinkan untuk bekerja di luar rumah kecuali dalam keadaan tertentu saja ${ }^{34}$.

Tenaga kerja di perkebunan tidak jarang mengalami nasib buruk, karena kedatangannya diperkebunan baik sebagai tenaga kerja atau calon istri. Para calon istri kadang tidak sampai pada calon suami karena keburu diambil orang lain. Dalam hal ini pihak atasan ikut campur dalam perjodohan tersebut. Jika pengawas Belanda menginginkan untuk dijadikan gundik atau Nyai maka perempuan diambil tanpa mengubris kepentingan calon suami ${ }^{35}$. Perjodohan seperti itu akhirnya menjadi umum dan "pergundikan" bentuk yang memenuhi kebutuhan yang mendapat toleransi masyarakat kulit putih, sedangkan kaum pribumi tak bisa berbuat apa-apa.

\footnotetext{
${ }^{32}$ Fauzie Ridjal, dkk. Eds. Dinamika Gerakan Perempuan di Indonesia. Yogyakarta: Tiara Wacana, 1993. hlm. 108.

${ }^{33}$ Ibid. hlm. 109.

${ }^{34}$ Ibid.
} 
Kehadiran perempuan di perkebunan kadang memicu konflik antara orang Jawa dan Cina atau antara orang Asia dan Belanda. Oleh karena Belanda yang pegang kekuasaan maka mereka punya hak pilih pertama ${ }^{36}$. Selanjutnya RP Suyono mencontohkan kejadian tanggal 1 Juni 1917 di Deli ada seorang administratur yang sedang bertugas memeriksa kuli laki-laki dan perempuan yang lewat, wanita yang cantik diberi tanda garis sebagai kode akan dipakai dikemudian hari. Perlakuan administratur dan asistennya tidak hanya membatasi diri pada perempuan lajang saja. Bahkan seorang kuli laki-laki mengadukannya pada yang berwenang di deli agar istrinya yang dipakai sebagai selir oleh asisten di perkebunan dapat dikembalikan ${ }^{37}$.

Di perkebunan teh paling tidak ada tiga faktor yang mendorong masuknya buruh perempuan diperkebunan yaitu komersialisasi tanah, industri ekonomi uang dan tingginya tingkat pengangguran. Penelitin Fatia menjelaskan terbukanya kesempatan bagi perempuan untuk bekerja sebagai buruh perkebunan telah menciptakan otonomi perempuan sepenuhnya dalam keluarga. Banyak perempuan melakukan poliandri atau menjadi istri simpanan mandor. Saat ini banyak perempuan juga meninggalkan keluarga untuk menjadi pekerja jauh dari desanya yaitu sebagai Tenaga Kerja Wanita, meskipun sering mendapat pelecehan seksual tetapi mereka tetap ingin pergi. Pelecehan seksual terhadap perempuan menurut teori feminisme sebagai akibat perbedaan jenis kelamin ${ }^{38}$. Sistem patriakal dianggap biang keladi ketidak setaraan antara laki-laki dan perempuan. Dalam sistem tersebut perempuan dianggap sebagai kelas dua baik di rumah tangga maupun di masyarakat.

\footnotetext{
${ }^{35}$ Sartono Kartodirdjo dan Djoko Suryo, op. cit. Hlm. 152.

${ }^{36}$ RP Suyono, op. cit. Hlm. 116.

${ }^{37}$ Ibid. hlm. 116-117.
} 


\section{E. Simpulan}

Stigma yang melekat pada perempuan sebagai mahkluk lemah dan tak berdaya, itu dapat ditanggulangi jika mendapat dukungan laki-laki untuk selalu melindunginya. Akan tetapi pria sebagai mahkluk yang kuat justru memperlakukan dengan tidak baik. Untuk itu perempuan harus memperjuangkan dirinya sendiri. Sebagai tenaga kerja yang selalu berada di luar rumah telah dilakukannya sejak lama, meskipun gender membuatnya diperlakukan beda dengan laki-laki. Akan tetapi kedudukannya yang terkait dengan simbol biologis justru menggambarkan kemampuan dan bernilainya perempauan, misalnya melahirkan, menyusui.

Kaum buruh sebagai lapisan paling bawah dalam hierarki perekonomian seakan menjadi keluarga lemah yang mudah diperdayakan. Berbagai bentuk derita menjadi cerita masa lalu tetapi perlu dilakukan perubahan. Saat ini keberadaan perempuan di luar rumah sangat dipengaruhi oleh berbagai faktor seperti tingkat pendidikan ikut menentukan kemampuannya menjaga dirinya sendiri. Akan menjadi seperti apa perempuan juga ditentukan oleh dirinya sendiri. Yang jelas sejarah telah mencatat keberadaannya di dalam rumah tangganya bukan sekedar simbol yang tanpa arti, tetapi justru sangat dibutuhkan. Daei mitos yang dibangun selama ini justru menunjukkan ketidakmampuan laki-laki untuk mengurus rumah tangganya tanpa didampingi istrinya.

\section{Daftar Pustaka}

Agus Joko Pitoyo. Pekerja Perempuan di Luar Negeri Melawan Pelecehan, Merajud Keberdayaan. Yogyakarta: Pusat Studi Kependudukan Kebijakan UGM, 2005,

\footnotetext{
${ }^{38}$ Agus Joko Pitoyo. Pekerja Perempuan di Luar Negeri Melawan Pelecehan, Merajud Keberdayaan. Yogyakarta: Pusat Studi Kependudukan Kebijakan UGM, 2005, hlm. 24.
} 
Boeke, JH. Pra Kapitalisme di Asia. Jakarta: Sinar Harapan, 1983.

Darsiti Soeratman. "Wanita Indonesia: Lampau, Kini dan Mendatang”. Pidato Ilmiah Dalam Rangka Acara Pembukaan Kuliah Prigram Pasca Sarjana Semester I di UGM, 2 September 1991.

Fatia Nadia. “Tenaga kerja Wanita di perkebunan Teh Malabar Afdelingen Cianjur Regenschapen Priangan Tahun 1880-1900”. Skripsi Sarjana Fakultas Sastra UGM tahun 1987.

Fauzie Ridjal, dkk. Eds. Dinamika Gerakan Perempuan di Indonesia. Yogyakarta: Tiara Wacana, 1993.

Handewi P Suliem. "Potensi dan Partisipasi Wanita Dalam kegiatan Ekonomi Pedesaan. Prisma Majalah Kajian Ekonomi dan Sosial No. 6 tahun 1992, LP3ES

http:/www. Nakertrans. Go.id/ pusdatinnaker/BPS/AK/AK\% 20 pulau jekel \% 20203 htm. 1/25/2005.

Irwan Abdullah. "Reproduksi Ketimpangan Gender Partisipasi Wanita dalam Kegiatan Ekonomi” Prisma Majalah Kajian Ekonomi dan sosial No. 6 Tahun 1995. LP3ES , ed. Sangkan Paran Gender. Yogyakarta: Pustaka Pelajar, 1997.

Kartini Syahrir. "Wanita: Beberapa Catatan Antropologi" Prisma majalah Ekonomi Sosial No. 101985 Th. XIV LP3ES, hal. 10.

Mansoer Fakih. Analisis Gender dan Transformasi Sosial. Yogyakarta: Pustaka Pelajar, 2001.

Mosse, Yulia Cleves. Gender Pembangunan. Yogyakarta: Pustaka Pelajar, 1996.

Mubyarto, dkk. Tanah dan Tenaga Kerja Perkebunan Kajian Sosial Ekonomi. Yogyakarta: Aditya Media, 1992

Ninasapti Triaswati. "Woman and Children Labour Force in the Indonesia". Indonesian Quarterly vol. XXIV no. 1 Tahun 1996, CSIS.

RP Suyono. Seks dan Kekerasan Pada Zaman Kolonial. Penelusuran Kepustakaan Sejarah. Jakarta: PT Gramedia Widia Sarana Indonesia, 2005, hal. 115-116

Sartono Kartodirdjo dan Djoko Suryo. Sejarah Perkebunan di Indonesia Kajian Sosial Ekonomi. Yogyakarta: Aditya Media, 1991.

Wolf, Eric R. Petani Suatu Tinjaun Antropologi. Jakarta: CV Rajawali, 1985 
